\title{
The use of valuations in residential property investment in
}

\author{
Australia \\ Vince Mangioni \\ University of Technology, Sydney \\ Vincent.mangioni@uts.edu.au
}

\begin{abstract}
Residential property investment for many purchasers is subject to finance. This finance is subject to two important criteria, the first criteria being the ability of the purchaser to service a loan and the second criteria and perhaps most crucial, is the relativity of the purchase price of property to its value.

This paper is a critique of the use of valuations in Australia used to engineer the lending of money against property after the purchase price has been determined. This is in contrast to the use of valuations prior to the purchase of property. A survey of several professions has been undertaken in determining the importance of a valuation in the property purchase process, which includes the formulation of the price to be paid for property.

In highlighting support for the use of valuations in the property purchase process prior to the purchase of residential property, this paper makes a contribution by defining the way valuers may be engaged by the borrower prior to purchase, rather than the long standing tradition of the valuer being solely engaged by the lender after the purchase price has been determined.
\end{abstract}




\section{I ntroduction}

Residential property as a home and increasingly as an investment vehicle is an object ive of many Australians in the pursuit of financial independence and self funded retirement. This desire has resulted in the proliferation of money lending and the systemic overpricing of property. The increase in debt for the funding of investment property has been aided through the use of mortgage brokers. Table 1 provides a snapshot of the increase in debt financing used to fund residential property investment in Australia.

Table 1: Housing Gearing Percentages

\begin{tabular}{|l|c|c|c|}
\hline & 1992 & 2002 & $\begin{array}{c}\% \text { Increase in } \\
\text { debt to asset } \\
\text { ratio }\end{array}$ \\
\hline Owner occupied property & 35.9 & 46.1 & 28.3 \\
\hline Investment property & 15.6 & 36.1 & 132 \\
\hline
\end{tabular}

Reserve Bank Australia 2003

The bi-product of the increase in lending has led to further fallout through the evolution of Collateralised Debt Obligations (CDO), which the Reserve Bank of Australia (2007) refers to as the synthetic use of property through derivatives written on the debt raised on property, without the actual physical holding of the property itself. The primary issue with these vehicles is that the CDO's are sold in groupings referred to as tranches. In many cases investors have purchased junior tranches of CDO's which are ranked behind senior tranches which have the first claim on the underlying assets.

As has been the case nationally and internationally the combined impact of both the financing of overpriced property followed by over investment in collateralised debt obligations has resulted in a serious meltdown in some property markets and impacted on the availability of finance which has been best exhibited in the U.S. through the subprime market fallout. In the first instance, the price paid for property and the funding of that purchase is the first step in the financial debt spiral. This issue is in fact fuelled by three key components:

1) Overpricing of p roperty;

2) Inability to service debt;

3) Over investment price paid for debt obligations derived from financing.

The complex structure of this phenomenon involves a number of professionals who deal in the sale, financing, valuation and purchase of property. As will be seen in the following 
analysis, the valuation profession is in part central to the underlying issue, but also potentially the answer to the resolution of the core underlying the issue.

\section{Defining the issue}

To define the issues in this paper a case study has been used to give context to the primary problem underlying buyer cognisance of the price paid for property. The following case is one example of the issues confronting uninformed purchasers of residential property, where the lender has superior knowledge however, the borrower chooses not to make the same inquiries as the lender and relies on their own judgement in the assessment of the purchase price of property.

\section{Case Facts}

The Gleesons purchased a property on the Gold Coast in Queensland Australia for a sum of $\$ 164,900$. The Commonwealth Bank (CBA) undertook a valuation of the property which showed the market value to be approximately $\$ 100,000$. The Gleesons tendered additional security to secure the loan over the property as well as other loans. The bank did not disclose the valuation to the Gleesons and proceeded with the loan. The matter was challenged in the court and the bank was brought to account for not disclosing the valuation to the purchasers who they had lent the money too. In reaching its conclusion, the court stated in ruling in favour of the bank:

The bank's terms and conditions should not be overlooked as unimportant. Clause 11.5 clearly advises the Gleesons that the bank would not be disclosing its valuation

The Commission submitted that the bank might avoid a finding of unconscionable conduct by simply advising the Gleesons to seek advice. $\mathrm{Mr} \&$ Mrs Gleeson were always able to obtain that advice, if not before their entry into contract, then afterwards. The only reasonable conclusion to be drawn from their continuing with the contract, in my view, was that Mr Gleeson wished to do so ${ }^{1}$

In summary, the court has ruled in favour of the bank and highlighted that each party to the transaction, including the transaction of borrowing money has a duty to themselves in making an informed decision as to value. The court has determined that the purchasers did not undertake this exercise or measure of due diligence in their decision

1 Australian Competition and Consumer Commission v Oceanna Commercial Pty Ltd [2003] FCA 1516 
to purchase the property. A lender is not an adviser, but is in the business of lending money for a return in which it must take the necessary steps to protect its position and business.

\section{Evolution of the Problem}

The primary issue of concern for government, consumers and now banks and lending institutions is the price paid for property which is ultimately funded by the lender. If the price is inflated at the time of purchase this has serious ramifications for the lender and also for the larger financial community which has become evident in the recent international financial meltdown. In essence two key problems are 'Loaded Pricing' and 'Two Tier Markets".

\section{Selling Property}

Two-tier marketing, put simply, is a process whereby uninformed purchasers buy property in a development at a higher price than informed purchasers. McDonald (1999) defines two-tier marketing as similar property exchanging at differing levels of market value. It involves inflated property prices to cover the additional cost of marketing and double commissions due to the large proportion of targeted investors coming from interstate and overseas (McDonald 1999).

Loaded-pricing or over pricing is the marketing of property based on depreciation and negative gearing benefits, rental income and capital growth. The selling price is loaded to cover an on-selling profit margin, broking and marketing costs over and above the market value, which many purchasers are typically unaware they are paying" (Australian Property Institute Victoria 2003:335).

Developers engage a mix of in-house marketers, financial planners and licensed agents to sell property (on completion and in some cases, off the plan). The MCCA (2004:16) state "property marketers have been primarily concerned to stimulate sales of real estate, especially of units in newly built or (more commonly) planned CBD apartment developments in, in particular, Melbourne, Sydney, Brisbane and Perth". In some circumstances, the developer has in-house financiers and solicitors / conveyancers, which the purchaser may be compelled to use, ASIC (2000). In other circumstances, the developer refers the purchaser to a panel of these professionals, who are promoted as being independent of the developer. In either case, these professionals are referred to as passive parties.

In each case, the in-house marketer, financial planner and agent are engaged and remunerated by the developer. These parties have no fiduciary obligation to the 
purchaser. In each case these parties act to sell property to the purchaser, using a variety of methods which include selling the merits of negative gearing, projected capital gains and the benefits of depreciation allowances. In some circumstances, valuations are provided by the developer, with some developers not permitting independent valuations to be undertaken by the purchaser.

\section{Selling Money \& Predat ory Lending Practices}

One of the areas of concern to regulators in Australia, following on from the lessons in the United States, is in the area of 'equity stripping' of people's homes. This is of particular importance where existing property with no or little debt, is used as leverage against loans to purchase other property. As highlighted in the following, this is achieved through reverse mortgages, in which Gilber and Reed (2003:3) state,

"Complete home ownership is often achieved in the middle to later years of the working life, when the mortgage is paid out. After retirement has commenced and a regular cash inflow has ceased, a reverse mortgage can commence. Over time, this will decrease the level of equity in the house, although the loan is structured so not all the equity is removed."

It is established in the United States that reverse mortgages were slow to commence; however, by 1999 more than 38,000 elderly homeowners had taken reverse mortgages. Whilst equity lending through reverse mortgages may be a useful way of funding retirement for some, a number of unconscionable practises have been identified. Smith (2003: 450) highlights,

"There is one breed of predator that doesn't prowl in the jungle. The predatory lender stalks consumers, seeking to seize their homes through high-cost, abusive lending practices. The elderly, people in low income brackets and those who are under financial pressure are often the targets" (CNN cited in Smith 2003:449)

"When Citigroup, the parent of a regulated lender, bought the Associates First Capital Corp. last year, and then were charged with predatory lending by the Justice Department, the company agreed to pay a fine, rather than suffer the bad publicity of a trial. So, Citicorp wrote a cheque for 27 million and was then out of the news and back to business."

In New South Wales Australia, as part of the conveyance process, which entails a mortgage, is the requirement for the conveyancer to explain the mortgage document to the client prior to their signing it. This to some degree assists the purchaser provided the 
conveyancer is arms length to the seller or developer. What this measure does not provide for, is a summary of the value of property to the sum of money being lent.

In cases where alternate property is not available for use as leverage, the use of mortgage insurance allows the lender to cover any potential losses that may arise. This insurance is paid for by the borrower and protects the lender. As noted in Table 2, the lender will mitigate their potential loss through the use of mortgage insurance, after which loans are securitised, bundled then sold off as collateralised debt obligations (CDOs). Also of particular note in this table, is the risk exposure to the valuer who writes the valuation at a fraction of the cost of the mortgage insurance cover. The valuation is in effect the insurance policy and the valuer is litigated by the lender in the event the price of the property is proven to have been in excess of the market value of the property.

Table 2: Mortgage insurance : valuation cost ratio

\begin{tabular}{|c|c|c|c|c|}
\hline Purchase price & $\begin{array}{c}\text { Loan : price } \\
\text { ratio }\end{array}$ & Insurance & Valuation fee & $\begin{array}{c}\text { Valuation fee } \\
\text { : insurance } \\
\text { ratio }\end{array}$ \\
\hline$\$ 500,000$ & $90 \%$ & $\$ 6,600$ & $\$ 220$ & $3.30 \%$ \\
\hline
\end{tabular}

Source: Yourmortgage.com.au

Valuations

Despite the use of valuations and the determination of value in the financing of property, it would be remiss to overlook the issues associated with this profession and their craft. The concern levelled at the independence of property valuers is illustrated by Wolverton \& Wolverton (1999), who asserts that in the United States, similar to the current mortgage market in Australia, draft reports are sent to clients for review. If the draft report does not meet the investment manager's needs, the appraiser is given the option of terminating the contract for a partial fee, or adjusting the value and completing the assignment for the full fee. Wolverton et al (1999:94) discuss the ramifications of this action;

\footnotetext{
“Terminating the contract may also result in the removal of the appraiser's firm from the investment managers approved roster of appraisers, effectively costing the firm a client. So the appraiser is forced to choose either to knowingly violate an ethical rule in order to satisfy a client of the firm, or to honour the ethical code and risk losing a client."
}

The routine practise of disclosing the sale price of a property being appraised is raised as an issue (Wolverton et al 1999). Empirical research undertaken by Gallimore and Wolverton, cited in Wolverton et al (1999), demonstrates appraisers are unable to ignore 
biases that sale price knowledge generates when solving valuation problems. Gallimore (in Black et al 2003) found that valuers may inappropriately give greatest weight to the most recently considered information. Further to this finding was that expert valuers indicated that they make early, preliminary judgements and then seek evidence in support of these opinions.

When contextualising the above concerns, Fischer (2002) highlights the importance of valuers placing emphasis on "diagnostics not prognosis" in their professional capacity. This important point requires the valuer to more importantly read the market rather than predict how it will react or perform. A cursory review of a sample of sales resulting in the process of writing a value does not constitute the primary task of the valuer. The role of the valuer is further defined as "Acting as valuers, like accountants, they must stick to facts, to things they can measure and ultimately to numbers they can defend in a Court of Law" (Fischer 2002:128). In the case of mortgage valuations, the purchase price of the subject property is only one of many factors to be diagnosed in determining its value along with the diagnosis of the market and other similar property transactions which can be measured (diagnosed) and defended in court.

\section{Solution and alternate model}

In addressing the issues identified in the case study and the circumstances of many inexperienced property investors and borrowers who finance property investment, a level of awareness is needed in the advice and sources of that advice which is to be relied upon. Of importance to an investor, particularly where finance is required for the purchase of property is the ability to understand the source, quality and most importantly the independence of advice.

Diagram 1 provides an additional layer of safety for the property purchaser which is shown as the divide of independence. This divide is an important point of recognition where the investor seeks independent advice from professionals, including valuers who are solely paid by them for advice about the property and its value. 


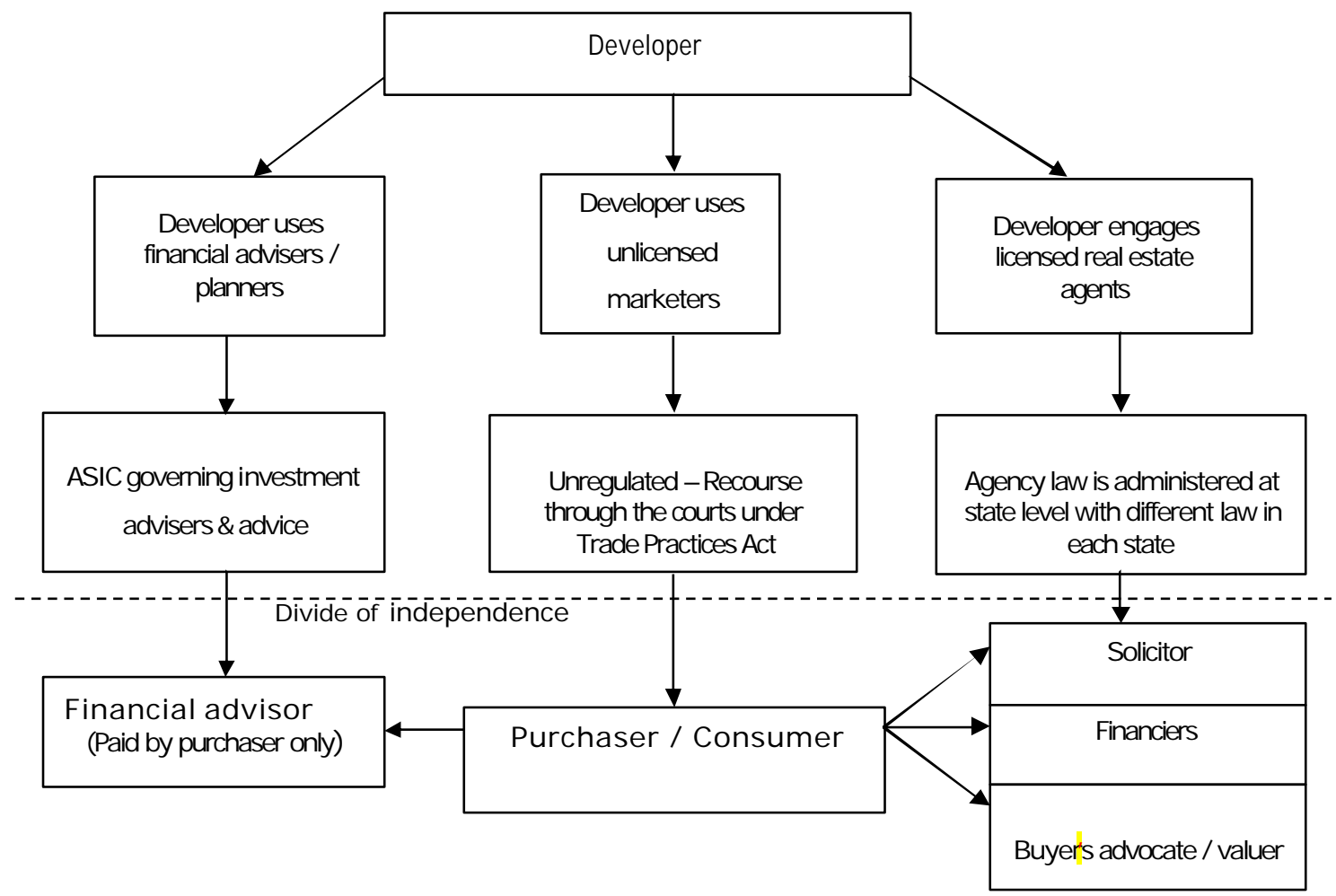

In considering the three points covered in the introduction, the overpricing of property is one issue that is the primary domain and concern of the valuer and valuation profession. At this point however, a segment of the residential valuation profession has not developed to establish itself as an independent viable alternative for property investors. Highly dependent on volume contract work, the valuation profession in this sector of the market is largely a masquerade for lending institutions, of which investors are financed to purchase property at their own peril.

In Australia the traditional use of valuations for mortgage lending purposes are commissioned by the lender after the agreed price of the property has been determined. This results in the valuers coming under pressure to write the purchase price of property as its value, "Recent experience has shown that current major mortgage lending institutions are applying great pressure for valuers to place greater emphasis on the subject sale" (Rooke 2002:48). In contrast to the pre deregulation of the banking industry in 1992 when valuers were directly employed by the banks, Mangioni (2006) highlights that valuers are now engaged by lenders under contract to confirm the purchase price of property as its value for the lowest possible fee. This has in fact been a major contributor to lending on over priced property. 
In addressing the issues arising from the above case, an alternate model for the investor follows next. This process shows the investor obtaining their own valuation from an approved valuer before agreeing on the purchase price which is then submitted to the lender to formalise and complete the sale if successfully negotiated by the purchaser.

In Diagram 2, the primary difference occurs as the stage of the formulation of the purchase price. Mangioni (2006) highlights the fact that far too often, the importance of this step is overlooked and becomes little more than a step in the buying process. In many cases investigations into the building condition, contract for the purchase and lending contract are investigated, with little or no real investigation into the price or value of the property to be purchased.

Despite the existing and alternate option in the above model, the potential for conflict, where lenders allow borrowers input in the valuation process, is highlighted by Crosby (2000) in referring to Banque Bruxelles Lambert SA v Eagle Star Insurance Co [1995] 1 EGLR 129 "The research issue is whether there is enough evidence of abuse in this process to prove that it impacts adversely on the efficiency of the lending process" (Crosby 2000:5). The example used is of the borrower or their broker seeking 'armchair valuations' from a succession of valuers and submitting the highest valuation to the lender. To elaborate on this proposition, the practise of obtaining 'armchair valuations' is not necessarily confined to the borrower or their broker, as the lender may also choose to do the same in writing a loan. By default, the valuer who allows his/her valuation to be assigned to the lender by the borrower is effectively assigning his/her valuation which constitutes an insurance policy to the lender. 
Diagram 2: Existing \& alternate purchase \& finance option model

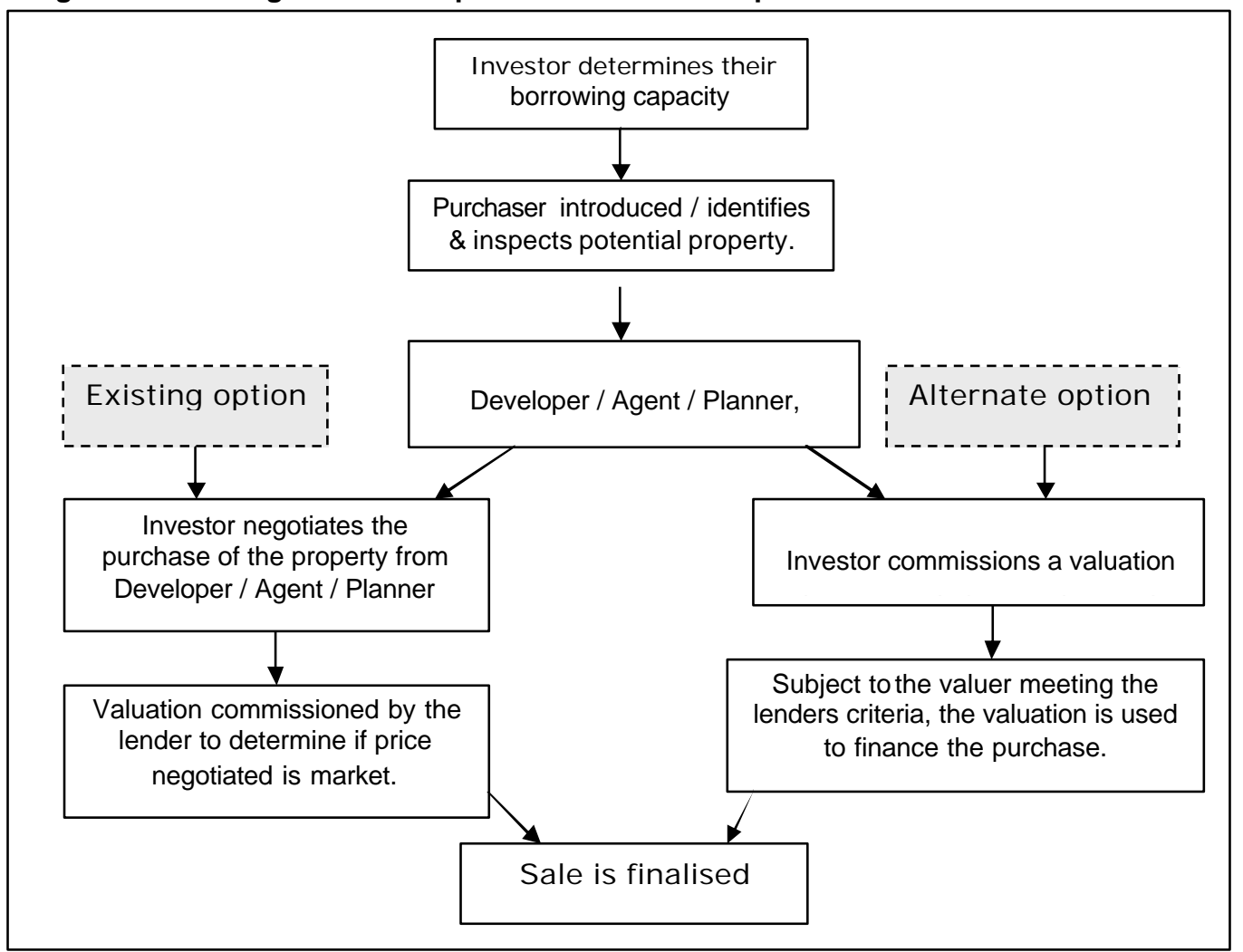

\section{Research method and rationale}

In assessing the response from property and associated professionals in the use of valuations by investors and home owners prior to purchase, a survey has been developed and used to measure this response. The survey includes real estate agents, buyer agents, valuers, financial planners, lenders, accountants and conveyancers. The survey determines the importance of the use of valuations prior to finalising the purchase price of property and ranks the use of valuations against other searches including building inspection reports, contracts for the sale of property, loan contracts and strata title reports.

\section{Statistical analysis and test}

A Likert Scale has been used to measure responses for the statements posed in the survey of which the scale comprises a range of 1 to 7 to measure responses on the following gradient:

1 - strongly agree

4 - unsure 


\section{7 - strongly disagree}

The statistical test used comprises two analyses, the first being the mean distribution for each professional group in which the mean of each professional group has been compared against each of the other professional groups. In addition, an analysis of the range distribution within each group has also been measured and plotted through the use of a mean distribution graph.

\section{Survey and response}

Response rates to surveys varied between the professions as shown in Table 3. Access to valuers, selling agents and lenders though professional bodies produced a higher return rate compared with other professionals. Surveys sent to Buyer's Agents were lowest due to their present numbers. A presentation of this research was made to the Buyer's Agent Committee of the REI to increase access to these professionals. It was confirmed by the committee that there is presently a limited number of Buyer Agents in both NSW and Australia. The specific number of buyer's agent in NSW could not be ascertained, since any holder of a real estate agents license qualifies as an agent to act as either a buyer's or a seller's agent, but not dually in the same transaction. The buyer's agents surveyed in this study exclusively acted for buyers only.

Table 3: Survey summary

\begin{tabular}{|l|c|c|}
\hline $\begin{array}{l}\text { Participants } \\
\text { Valuer }\end{array}$ & $\begin{array}{c}\text { Surveys Sent } \\
70\end{array}$ & $\begin{array}{c}\text { Response } \\
76 \%\end{array}$ \\
\hline Real Estate Agent (selling) & 70 & $56 \%$ \\
\hline Buyers Agent & 40 & $33 \%$ \\
\hline Financial Planner & 70 & $27 \%$ \\
\hline Accountant & 70 & $27 \%$ \\
\hline Solicitors / Conveyancer & 70 & $29 \%$ \\
\hline Lenders & 70 & $47 \%$ \\
\hline Totals & 460 & $43 \%$ \\
\hline
\end{tabular}

\section{Survey statements}

Statement 1: A valuation would assist an investor when purchasing residential property.

Statement 2: A strata inspection report would assist an investor when purchasing residential property

Statement 3: A building and pest report would assist an investor when purchasing residential property

Statement 4: A legal opinion of the contract of sale would assist an investor when purchasing residential property 
Statement 5: A legal opinion of the loan agreement would assist an investor when purchasing residential property

\section{Summary of Statements 1 - 5}

In confirming the relevance and benefits of valuations in the property purchase process, the professionals surveyed have ranked the importance of valuations among other documents obtained. Table 4 is a summary of Statements 1-5 of the survey which has resulted in the following ranking of documents that would assist investors purchase property. In compiling Table 4, the combined median for each statement by all professionals was used to determine an industry ranking of the importance of each documents in the purchase process.

Table 4: Professionals ranking of property related documents ( $\mathrm{e}=$ equal)

\begin{tabular}{|c|cc|c|c|c|c|c|c|}
\hline & Valuer & $\begin{array}{c}\text { Selling } \\
\text { Agent }\end{array}$ & $\begin{array}{c}\text { Buyer } \\
\text { Agent }\end{array}$ & $\begin{array}{c}\text { Financial } \\
\text { Planner }\end{array}$ & $\begin{array}{c}\text { Solicitor/ } \\
\text { Conveyancer }\end{array}$ & Accountant & Lender & Rank \\
\hline Valuation & 2 & 1.7 & 1.4 & 2.2 & 2.6 & 1.3 & 1.9 & $\mathbf{3 e}$ \\
\hline $\begin{array}{c}\text { Strata } \\
\text { report }\end{array}$ & 2 & 1.6 & 1.2 & 2.2 & 1.7 & 1.2 & 1.9 & $\mathbf{2}$ \\
\hline $\begin{array}{c}\text { Building } \\
\text { \& pest }\end{array}$ & 1.9 & 1.6 & 1.5 & 2 & 1.7 & 1.1 & 1.6 & $\mathbf{1}$ \\
\hline $\begin{array}{c}\text { Sale } \\
\text { contract }\end{array}$ & 2 & 1.9 & 1.8 & 2.4 & 2 & & & \\
\hline $\begin{array}{c}\text { Loan } \\
\text { contract }\end{array}$ & 2.3 & 2 & 2.7 & 2.5 & 2.1 & 1.4 & 1.9 & $\mathbf{3 e}$ \\
\hline
\end{tabular}

\section{Response commentary}

The above table confirms that valuations do have a place among the information to be considered by purchasers, which is ranked equal third with advice on the contract of sale. In relation to each of these documents, a brief summary is provided. A statistical analysis of the results for each statement is provided as an annexure.

\section{Valuation report}

In contrast to all the professions surveyed, conveyancer's appeared to be only marginally in agreement with the statement. Discussions with conveyancers provided some basis for the result. Overall valuations are seen to be based on another person's view of value, even though a valuer is a recognised professional. The conveyance of property is seen as a process of imparting information on to buyers. It is an integral part of the buying process. The valuation is seen to go beyond the scope of providing information, due to the fact that a valuation is an opinion of value, not a definitive statement of fact. In many ways, whilst it is recognised that a valuation may assist an 
investor not to pay beyond the value for a property, a trade-off is made between this and the potential for a valuation to provide an additional issue that may thwart or impact on the purchase. Traditionally, the valuation has not been a recommendation made by conveyancers and at present has been met with some resistance by this profession.

Of particular note is the comparison between the selling agent, who acts for the seller, and the valuer, who at present can be identified as acting for the lender as most valuations at present would be commissioned by the lender rather than the investor. In the present case, the mean of the valuer's range is very similar to the mean of the selling agent. In the present valuation process, the valuer will contact the selling agent to discuss the method of sale and bona fides of the transaction and parties to it. This primarily occurs as the valuer is traditionally engaged post purchase to analyse the transaction and confirm value within the context of what the purchaser has paid for the subject property. This is in contrast to the valuer determining the relativity of the value of the property against other property sold prior to purchase.

\section{Strata report}

The relevance of the strata inspection report is of lower relevance in the present study, as this work is primarily looking at new residential property, of which there would be little or no information relating to the history in the case of residential strata units and townhouse development. Despite this fact, overall, the strata inspection report provides a wealth of information in relation to the financial, physical and personality of the property, where a history does exist. An additional aspect that is relevant to the new residential development exists where the property is sold off new with a sinking fund included with the scheme. Ultimately, the purchaser would pay for this, but may be comforted in knowing that the provision for capital expenditure has been considered from the outset of the development.

\section{Building \& pest report}

The results of the benefits of the building and pest reports provide an interesting variety of responses, particularly from buyer agents, valuers and conveyancers. The confidence interval of buyer agents and conveyancers, whilst generally affirming the benefits of these reports, have a variety of opinions within the professional group, compared with selling agents who have the equal second lowest confidence interval with lenders. Selling agents are also noted for having the second lowest mean distribution behind accountants. 
The last profession for comment are valuers, who registered the second highest mean of all professions. In many valuations undertaken by valuers, the use of disclaimers for structural and building defects is a requirement of professional indemnity insurers. Whilst valuers will note obvious building defects, these are outside their scope of expertise, which in part is reflected in their survey responses when compared with other professionals.

\section{Sale contract}

The contract of sale and terms and conditions of sale, whilst important, impact on the transaction and the implications for the purchaser more specifically. This is due to the contract of sale be ing prepared by the seller. In the case of new residential property, the contract of sale is crucial in articulating whether the sale price of the property is GST inclusive or exclusive. The contract of sale may also provide penalty provisions for nonperformance and late settlement provisions, which may also be prohibitive. Adjustments for land tax and payments of land tax for property purchased off the plan may also be accrued and charged to the purchaser. These matters, among others, need to be considered when assessing the purchase price for a property.

\section{Loan contract}

The implications of the mortgage agreement may impact on the borrower for the term of the Ioan. One particular issue of note is the proliferation of mortgage brokers over the past 5 - 10 years. With brokers tapping into sources for lending, real estate and real estate practitioners are of interest to mortgage lenders and brokers, particularly professionals involved with investors and purchasers who may require finance to purchase investment $p$ roperty.

In this survey, it is noted that all professionals had mean distributions on the affirmative side and agreed with the statement to varying degrees. Buyer agents and financial planners have broad mean distributions within their groups, with the upper limit of the distribution close to 4 being unsure. The mean of each group is between 2.5 and 3 . As highlighted earlier, the provision of finance is a service in which remuneration for referrals are common. In cases where referrals are made and fees are paid for such referrals, regardless of the disclosures to the purchaser of that fee or commission, unless the referring party has access to all lenders and are paid equal fees or commissions from each, it is important that all mortgage lending agreements are commented on by an independent source to the agreement. 


\section{Conclusion}

The causes contributing too and the responses needed for averting the problems currently embracing world financial markets are diverse and complex. In the case of property and its financing, a contribution can be made in a number of ways in which the valuer and valuation profession are key contributors to this response. At the micro level, property investors have the option of better informing themselves about property and the market in which property exists through the use of valuers. Given that many property purchases involving finance are the subject of valuations by lenders, the purpose of this practise should be more evident to investors prior to determining the purchase price of property. This has yet to become a mainstream approach, however in view of the present market turmoil, there is no better time for this approach to be adopted.

The contribution that valuations offer in assisting property investors are evident in the survey findings reported in this paper. It is clear that all professions endorse the use of valuations by investors prior to purchase and the benefits this affords cannot be underestimated. It is important in evolving the understanding and use of valuations by investors, that the valuation profession assist investors in understanding the use and importance of their profession. In the regulatory safeguards and governance provisions that would assist in protecting the financial market in the future, regulators cannot solely be responsible for poor consumer decision making in the area of property investment and the price paid for property. This objective needs to be achieved through better financial literacy which includes the benefits of understanding property values through the use of valuations. 


\section{References}

Australian Property Institute (Vic) 2003, 'Loaded-pricing and two-tier marketing', Australian Property Journal, vol. 37, no. 5, pp. 335-337.

Australian Securities Investment Commission 2000, A summary of findings - ASIC review of financial advising activities of real estate agents.

Black.R.T, B.M.G., Diaz.J, Gilber.K.M Grissom.T.V., 2003, 'Behavioral Research in Real Estate', J ournal of Real Estate Practice and Education, vol. 6, no. 1, pp. 85-112.

Crosby, N. 2003, 'Valuation accuracy: reconciling the timing of the valuation and sale', European Real Estate Society, Helsinki Finland.

Fischer, D. 2002, Property Valuation Methodology, Black Swan Press Perth

Gilber, M.K., \& Reed, R. 2003, 'The case for Reverse Mortgages in Australia - Applying the USA Experience.' 9th Annual Pacific Rim Real Estate Society Conference, Brisbane.

Mangioni. V 2006, 'Valuing the purchase price of property - Is the purchase price of property the best evidence of value?' Pacific Rim Real Estate Conference, Auckland.

McDonald, G. 1999, 'Two-tier Markets', Australian Property Journal, vol. 35, pp. 516523.

Ministerial Council on Consumer Affairs Working Party 2004, (MCCA) Property Investment Advice Discussion Paper, Brisbane.

Reserve Bank of Australia 2003, 'Do Australian Households Borrow Too Much?' Talk to the Sydney Institute, Sydney.

Rooke, C. 2002, 'Boom-time valuations: the difficult decisions', Property Journal, vol. 37, no. 1, pp. $48-49$.

Smith, S. 2003, 'Predatory lending, mortgage fraud, and client pressures', Australian Property J ournal, vol. May 2003, pp. 449-459.

Wolverton, M.L., and Wolverton, M. 1999, 'TOWARDS A COMMON PERSEPTION OF ETHICAL BEHAVIOR IN REAL ESTATE', Research Issues in Real Estate, vol. 5, pp. 89-106. 


\section{Cases}

Australian Competition and Consumer Commission v Oceanna Commercial Pty Ltd [2003] FCA 1516

Banque Bruxelles Lambert SA v Eagle Star Insurance Co [1995] 1 EGLR 129 
Statement 1 - A valuation would assist an investor when purchasing residential property.

Mean Analysis

\begin{tabular}{|c|c|c|c|c|c|c|c|c|}
\hline & \multirow[t]{2}{*}{$\mathrm{N}$} & \multirow[t]{2}{*}{ Mean } & \multirow[t]{2}{*}{$\begin{array}{c}\text { Std. } \\
\text { Deviation }\end{array}$} & \multirow[t]{2}{*}{$\begin{array}{l}\text { Std. } \\
\text { Error }\end{array}$} & \multicolumn{2}{|c|}{$\begin{array}{l}95 \% \text { Confidence } \\
\text { Interval for Mean }\end{array}$} & \multirow[t]{2}{*}{ Min } & \multirow[t]{2}{*}{ Max } \\
\hline & & & & & $\begin{array}{l}\text { Lower } \\
\text { Bound }\end{array}$ & $\begin{array}{l}\text { Upper } \\
\text { Bound }\end{array}$ & & \\
\hline Buyer agent & 13 & 1.38 & 0.768 & .213 & 0.92 & 1.85 & 1 & 3 \\
\hline Selling agent & 39 & 1.69 & 1.321 & .212 & 1.26 & 2.12 & 1 & 7 \\
\hline Valuer & 52 & 1.98 & 1.350 & .187 & 1.60 & 2.36 & 1 & 7 \\
\hline Lender & 33 & 1.94 & 1.435 & .250 & 1.43 & 2.45 & 1 & 7 \\
\hline Financial planner & 19 & 2.21 & 1.873 & .430 & 1.31 & 3.11 & 1 & 7 \\
\hline Conveyancer & 20 & 2.60 & 1.536 & .343 & 1.88 & 3.32 & 1 & 7 \\
\hline Accountant & 19 & 1.26 & 0.653 & .150 & 0.95 & 1.58 & 1 & 3 \\
\hline Total & 195 & 1.89 & 1.386 & .099 & 1.70 & 2.09 & 1 & 7 \\
\hline
\end{tabular}

ANOVA Result

\begin{tabular}{|c|c|c|c|c|c|}
\hline & $\begin{array}{l}\text { Sum of } \\
\text { Squares }\end{array}$ & $d f$ & $\begin{array}{c}\text { Mean } \\
\text { Square }\end{array}$ & $\mathrm{F}$ & Sig. \\
\hline $\begin{array}{l}\text { Between } \\
\text { Groups }\end{array}$ & 24.852 & 6 & 4.142 & \multirow[t]{3}{*}{2.238} & \multirow[t]{3}{*}{.041} \\
\hline Within Groups & 347.886 & 188 & 1.850 & & \\
\hline Total & 372.738 & 194 & & & \\
\hline
\end{tabular}

\section{Graph - Mean Distribution}

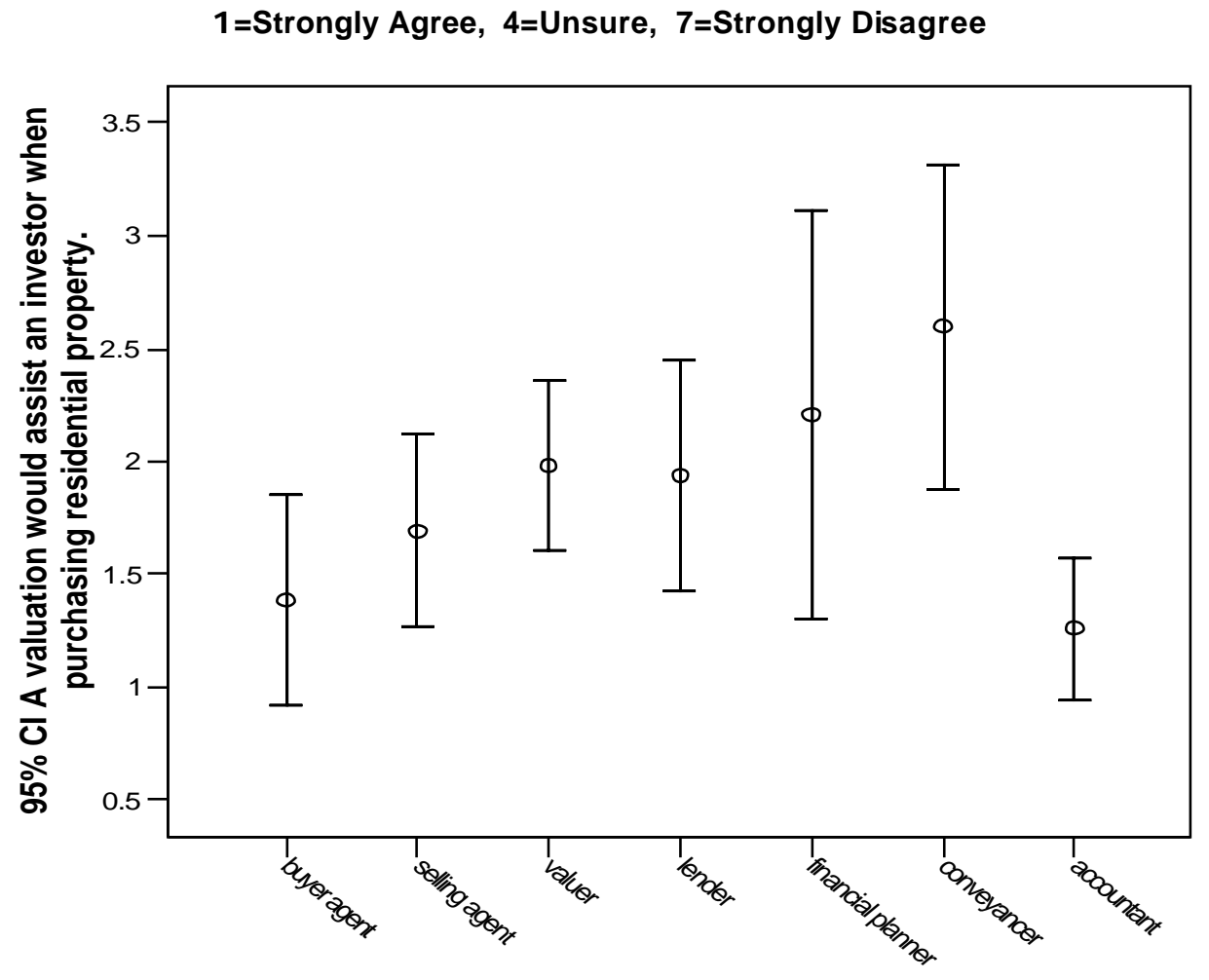

Respondent's Profession 
Statement 2 - A strata inspection report would assist an investor when purchasing residential property.

Mean Analysis

\begin{tabular}{|l|r|r|rr|r|rrr|}
\hline & \multicolumn{1}{|c|}{$\mathrm{N}$} & Mean & $\begin{array}{c}\text { Std. } \\
\text { Deviation }\end{array}$ & $\begin{array}{c}\text { Std. } \\
\text { Error }\end{array}$ & \multicolumn{2}{|c|}{$\begin{array}{c}\text { 95\% Confidence } \\
\text { Interval for Mean }\end{array}$} & Min & $\begin{array}{c}\text { Maxi } \\
\text { mum }\end{array}$ \\
\hline & & & & & \multicolumn{2}{c}{$\begin{array}{c}\text { Lower } \\
\text { Bound }\end{array}$} & $\begin{array}{c}\text { Upper } \\
\text { Bound }\end{array}$ & \\
\hline Buyer agent & 13 & 1.23 & .439 & .122 & .97 & 1.50 & 1 & 2 \\
Selling agent & 39 & 1.62 & 1.227 & .197 & 1.22 & 2.01 & 1 & 7 \\
Valuer & 52 & 1.96 & 1.328 & .184 & 1.59 & 2.33 & 1 & 7 \\
Lender & 33 & 1.94 & 1.273 & .222 & 1.49 & 2.39 & 1 & 7 \\
Financial planner & 19 & 2.21 & 1.873 & .430 & 1.31 & 3.11 & 1 & 7 \\
Conveyancer & 20 & 1.70 & 1.380 & .309 & 1.05 & 2.35 & 1 & 7 \\
Accountant & 19 & 1.16 & .501 & .115 & .92 & 1.40 & 1 & 3 \\
Total & 195 & 1.76 & 1.292 & .092 & 1.58 & 1.94 & 1 & 7 \\
\hline
\end{tabular}

ANOVA Result

\begin{tabular}{|l|ccc|cc|}
\hline & $\begin{array}{c}\text { Sum of } \\
\text { Squares }\end{array}$ & df & $\begin{array}{c}\text { Mean } \\
\text { Square }\end{array}$ & F & Sig. \\
\hline Between Groups & 18.447 & 6 & 3.075 & 1.894 & .084 \\
Within Groups & 305.225 & 188 & 1.624 & & \\
Total & 323.672 & 194 & & & \\
\hline
\end{tabular}

\section{Graph - Mean Distribution}

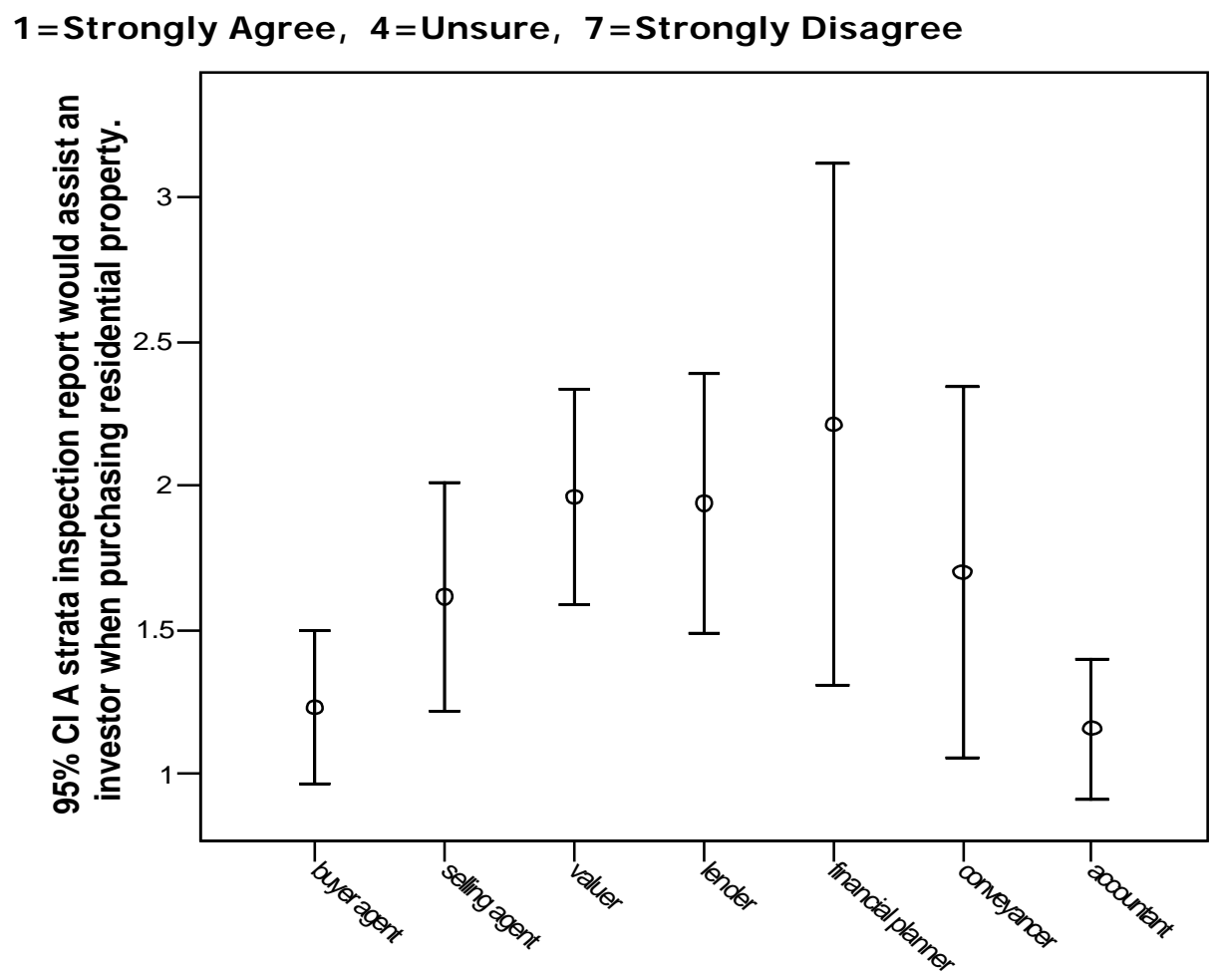

Respondent's Profession 
Question 3 - A building and pest report would assist an investor when purchasing residential property.

Mean Analysis

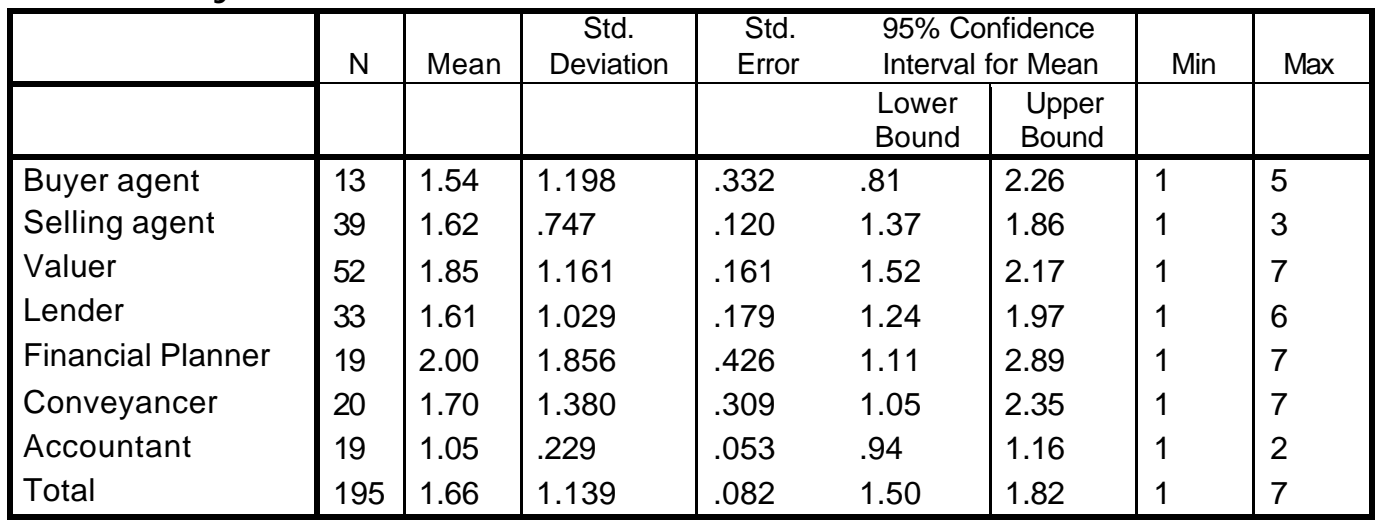

ANOVA Result

\begin{tabular}{|l|r|r|c|c|c|}
\hline & $\begin{array}{c}\text { Sum of } \\
\text { Squares }\end{array}$ & \multicolumn{1}{c|}{ df } & $\begin{array}{c}\text { Mean } \\
\text { Square }\end{array}$ & F & Siq. \\
\hline Between Groups & 11.405 & 6 & 1.901 & 1.487 & .185 \\
Within Groups & 240.257 & 188 & 1.278 & & \\
Total & 251.662 & 194 & & & \\
\hline
\end{tabular}

Graph - Mean Distribution

$1=$ Strongly Agree, $4=$ Unsure, $7=$ Strongly Disagree

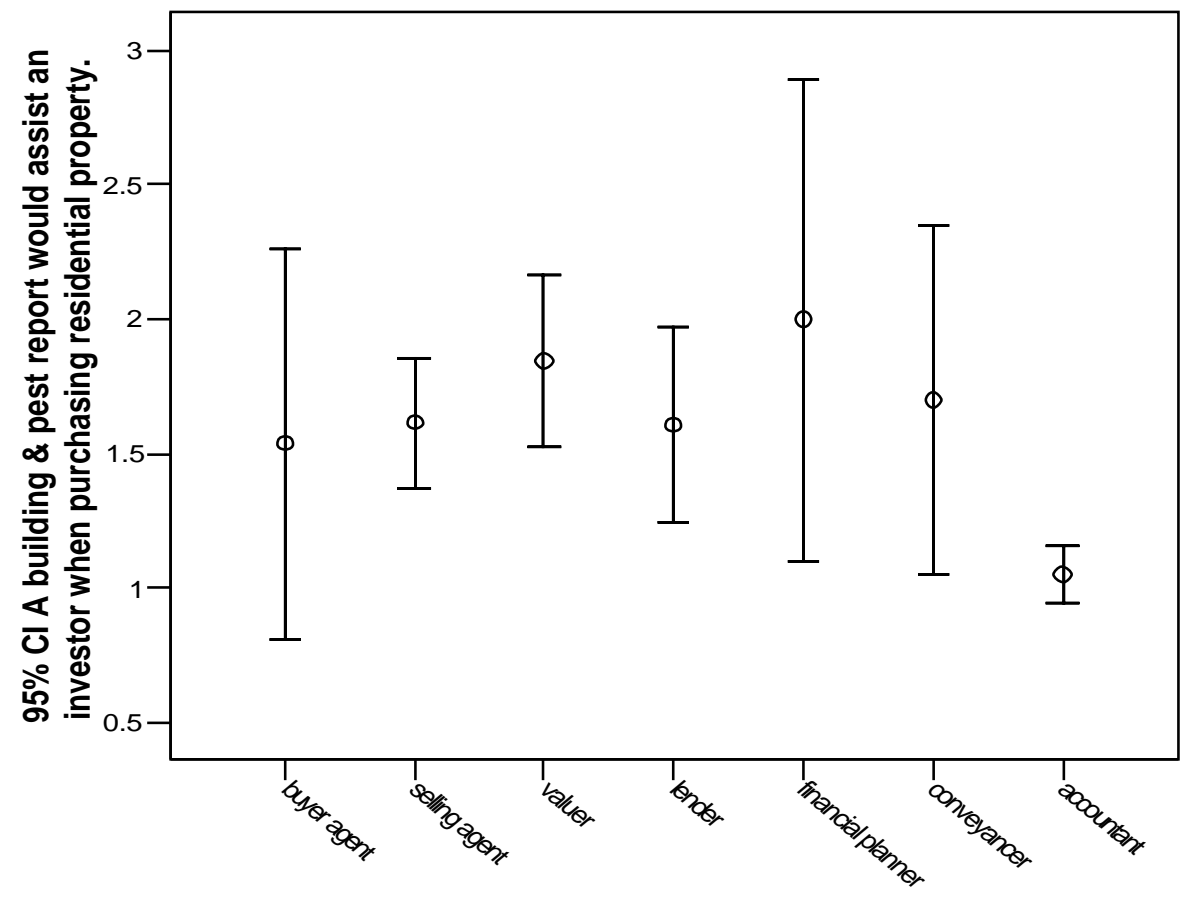

Respondent's Profession 
Statement 4 - A legal opinion of the contract of sale would assist an investor when purchasing residential property.

\section{Mean Analysis}

\begin{tabular}{|c|c|c|c|c|c|c|c|c|}
\hline & \multirow[t]{2}{*}{$\mathrm{N}$} & \multirow[t]{2}{*}{ Mean } & \multirow[t]{2}{*}{$\begin{array}{c}\text { Std. } \\
\text { Deviation } \\
\end{array}$} & \multirow[t]{2}{*}{$\begin{array}{l}\text { Std. } \\
\text { Error }\end{array}$} & \multicolumn{2}{|c|}{$\begin{array}{l}\text { 95\% Confidence } \\
\text { Interval for Mean }\end{array}$} & \multirow[t]{2}{*}{ Min } & \multirow[t]{2}{*}{ Max } \\
\hline & & & & & $\begin{array}{l}\text { Lower } \\
\text { Bound }\end{array}$ & $\begin{array}{l}\text { Upper } \\
\text { Bound }\end{array}$ & & \\
\hline Buyer agent & 13 & 1.77 & 1.013 & .281 & 1.16 & 2.38 & 1 & 4 \\
\hline Selling agent & 39 & 1.87 & 1.735 & .278 & 1.31 & 2.43 & 1 & 7 \\
\hline Valuer & 52 & 1.96 & 1.252 & .174 & 1.61 & 2.31 & 1 & 7 \\
\hline Lender & 33 & 1.91 & 1.234 & .215 & 1.47 & 2.35 & 1 & 7 \\
\hline $\begin{array}{l}\text { Financial } \\
\text { planner }\end{array}$ & 19 & 2.42 & 2.090 & .479 & 1.41 & 3.43 & 1 & 7 \\
\hline Conveyancer & 20 & 2.00 & 1.622 & .363 & 1.24 & 2.76 & 1 & 7 \\
\hline Accountant & 19 & 1.11 & .315 & .072 & .95 & 1.26 & 1 & 2 \\
\hline Total & 195 & 1.89 & 1.442 & .103 & 1.68 & 2.09 & 1 & 7 \\
\hline
\end{tabular}

ANOVA Result

\begin{tabular}{|l|rrr|r|l|}
\hline & \multicolumn{1}{|c|}{$\begin{array}{c}\text { Sum of } \\
\text { Squares }\end{array}$} & df & $\begin{array}{c}\text { Mean } \\
\text { Square }\end{array}$ & F & Sig. \\
\hline Between Groups & 17.780 & 6 & 2.963 & 1.444 & .200 \\
Within Groups & 385.738 & 188 & 2.052 & & \\
Total & 403.518 & 194 & & & \\
\hline
\end{tabular}

\section{Graph - Mean Distribution}

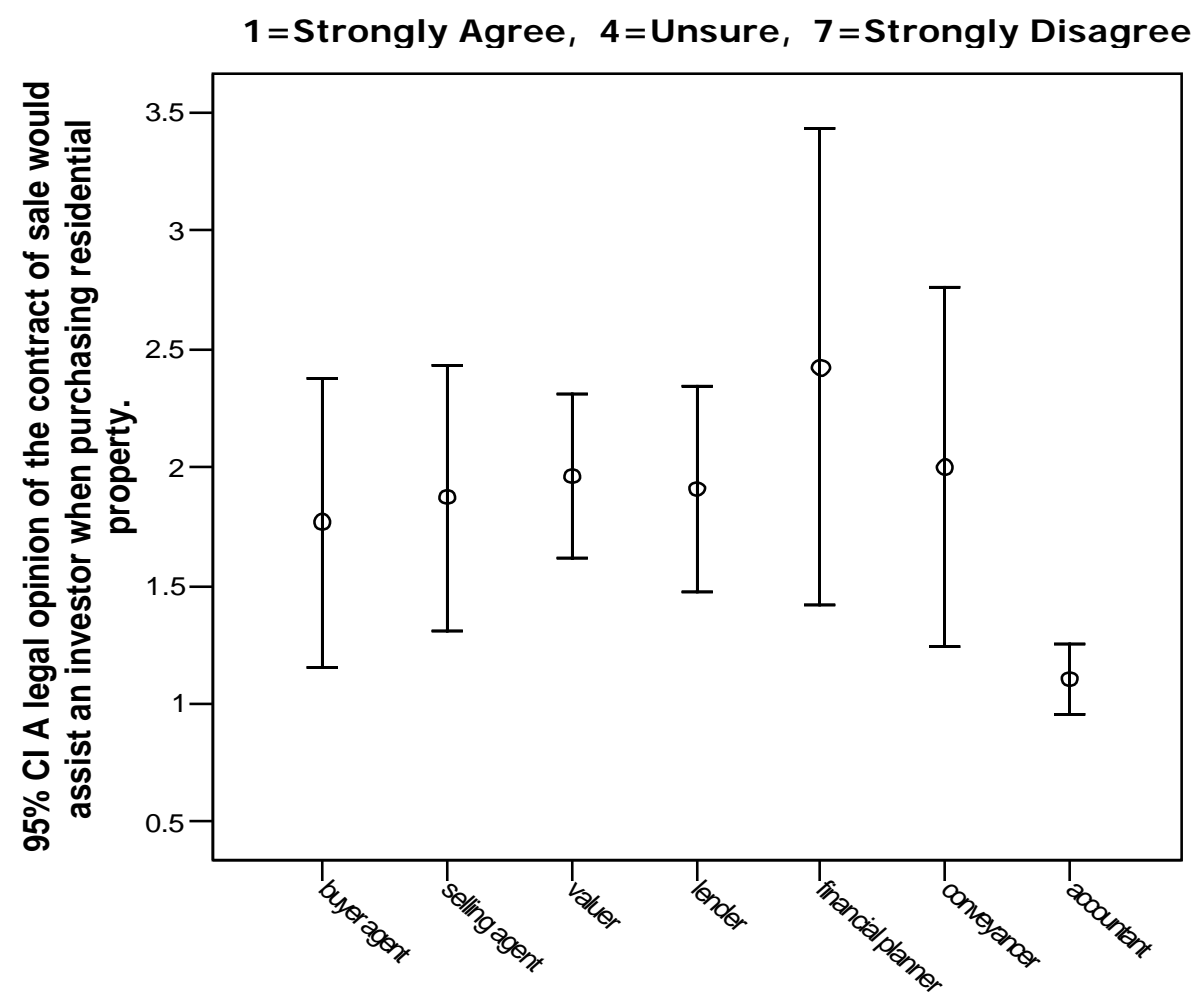

Respondent's Profession 
Statement 5 - A legal opinion of the loan agreement would assist an investor when purchasing residential property.

Mean Analysis

\begin{tabular}{|c|c|c|c|c|c|c|c|c|}
\hline & \multirow[t]{2}{*}{$\mathrm{N}$} & \multirow[t]{2}{*}{ Mean } & \multirow[t]{2}{*}{$\begin{array}{l}\text { Std. } \\
\text { Deviat } \\
\text { ion }\end{array}$} & \multirow[t]{2}{*}{$\begin{array}{l}\text { Std. } \\
\text { Error }\end{array}$} & \multicolumn{2}{|c|}{$\begin{array}{l}95 \% \text { Confidence } \\
\text { Interval for Mean }\end{array}$} & \multirow[t]{2}{*}{ Min } & \multirow[t]{2}{*}{ Max } \\
\hline & & & & & $\begin{array}{l}\text { Lower } \\
\text { Bound }\end{array}$ & $\begin{array}{l}\text { Upper } \\
\text { Bound }\end{array}$ & & \\
\hline Buyer agent & 13 & 2.69 & 1.601 & .444 & 1.72 & 3.66 & 1 & 6 \\
\hline Selling agent & 39 & 2.03 & 1.709 & .274 & 1.47 & 2.58 & 1 & 7 \\
\hline Valuer & 52 & 2.27 & 1.430 & .198 & 1.87 & 2.67 & 1 & 6 \\
\hline Lender & 33 & 2.42 & 1.458 & .254 & 1.91 & 2.94 & 1 & 6 \\
\hline Financial planner & 19 & 2.53 & 2.144 & .492 & 1.49 & 3.56 & 1 & 7 \\
\hline Conveyancer & 20 & 2.10 & 1.651 & .369 & 1.33 & 2.87 & 1 & 7 \\
\hline Accountant & 19 & 1.42 & .769 & .176 & 1.05 & 1.79 & 1 & 3 \\
\hline Total & 195 & 2.20 & 1.572 & .113 & 1.98 & 2.42 & 1 & 7 \\
\hline
\end{tabular}

ANOVA Result

\begin{tabular}{|l|ccc|cc|}
\hline & $\begin{array}{l}\text { Sum of } \\
\text { Squares }\end{array}$ & df & $\begin{array}{c}\text { Mean } \\
\text { Square }\end{array}$ & $F$ & Sig. \\
\hline Between Groups & 19.997 & 6 & 3.333 & 1.364 & .231 \\
Within Groups & 459.203 & 188 & 2.443 & & \\
Total & 479.200 & 194 & & & \\
\hline
\end{tabular}

Graph - Mean Distribution

1=Strongly Agree, 4=Unsure, 7=Strongly Disagree

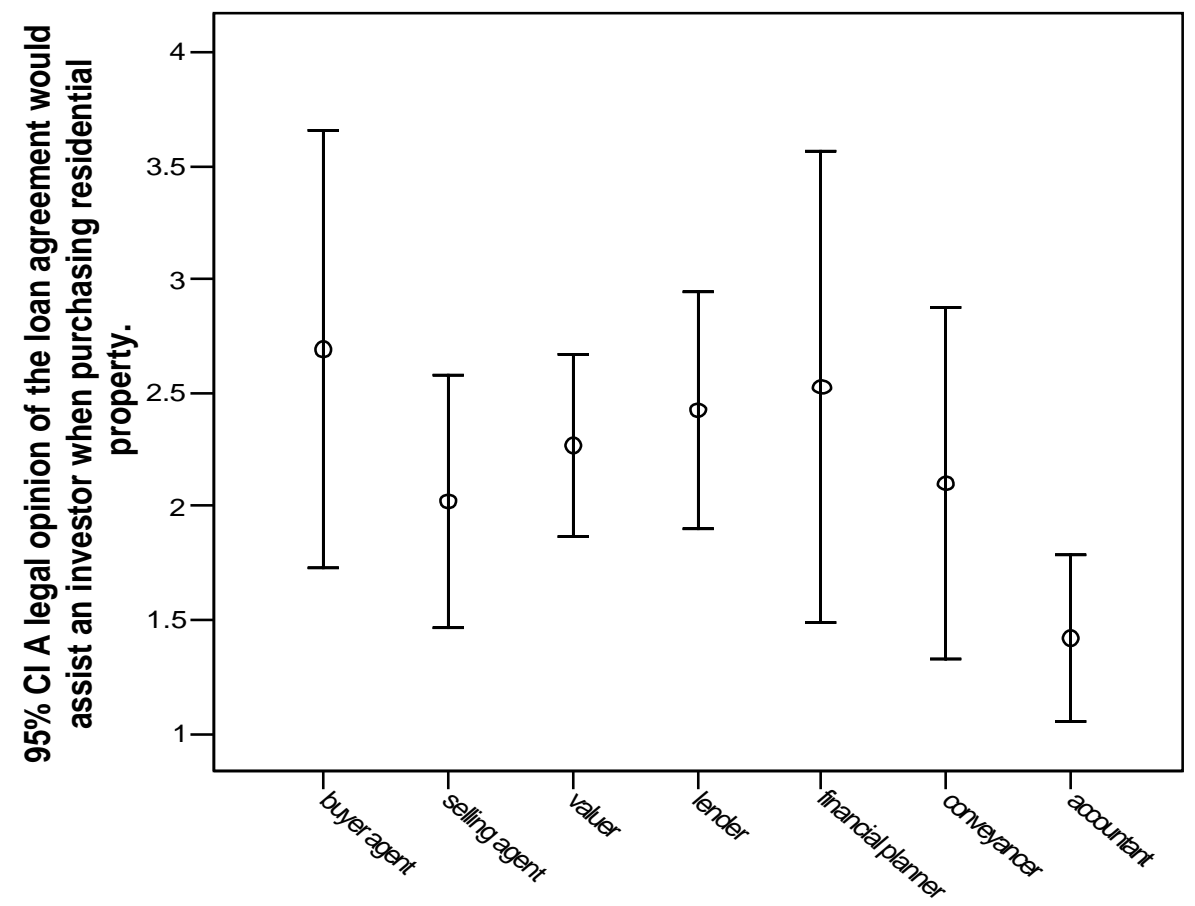

Respondent's Profession 